\title{
The Impact of Climate Change in Hong Kong and the Pearl River Delta
}

Alexandra Tracy, Kate Trumbull et Christine Loh

\section{OpenEdition}

\section{Journals}

Édition électronique

URL : http://journals.openedition.org/chinaperspectives/1173

DOI : 10.4000/chinaperspectives. 1173

ISSN : 1996-4617

Éditeur

Centre d'étude français sur la Chine contemporaine

\section{Édition imprimée}

Date de publication : 15 janvier 2007

ISSN : 2070-3449

Référence électronique

Alexandra Tracy, Kate Trumbull et Christine Loh, « The Impact of Climate Change in Hong Kong and the Pearl River Delta », China Perspectives [En ligne], 2007/1 | 2007, mis en ligne le 08 avril 2008, consulté le 28 octobre 2019. URL : http://journals.openedition.org/chinaperspectives/1173 ; DOI : 10.4000/chinaperspectives. 1173 
L

\title{
Impact of Climate Change
}

in Hong Kong and the

Pearl River Delta

\author{
ALEXANDRA TRACY, KATE TRUMBULL \\ AND CHRISTINE LOH ${ }^{(1)}$
}

This article represents a first attempt to pull together relevant materials with the aim of providing a broad-brush view of how climate change may affect Greater Pearl River Delta (GPRD) region (Hong Kong, Macau and the Pearl River Delta). Among the various consequences of climate change, rising sea levels are a matter of great concern for the GPRD region, which is made vulnerable both by its physical geography (the southern part of the delta lies between $0.3 \mathrm{~m}$ to $0.4 \mathrm{~m}$ relative to mean sea level (MSL)) and its urban development. More in-depth research and modeling remain to be done so that the authorities, business and civil society can better understand climate impacts on the region, but this article shows that climate change could have a big impact on the regional economy, which represents nearly $10 \%$ of China's GNP. The paper concludes with a discussion of the measures that government and businesses will need to consider in order to adapt to these future conditions.

$\mathrm{C}$ hina's fast-growing contribution to global warming is well recognised. The largest emitter of the greenhouse gases that are believed to accelerate warming is currently the United States, but industrialising China is catching up rapidly. The GPRD region of Guangdong province is one of the world's leading manufacturing centres (representing nearly 10\% of China's GNP), itself becoming a major contributor to China's emissions total. The physical realities of climate change are already being felt in many parts of China: from drought, to floods, to a demonstrable rise in sea level. The GPRD region faces a severe threat on two fronts: firstly, in that it is particularly vulnerable to the effects of climate change, especially a rise in sea levels; and secondly in that it is one of the wealthiest areas in China, with much to lose.

Because climate change is expected to happen over decades or centuries, policy-makers seem to succumb to the phenomenon of "creeping normalcy": that is, a failure to recognise fully that conditions are worsening because the baseline standard for what is "normal" is gradually shifting ${ }^{(2)}$. Other issues appear far more immediate, and industrial development and rapid economic growth tend to take priority in the decision-making process. The purpose of this article is to demonstrate that climate change is not a remote possibility, and that its impact on the economy of the GPRD region could be considerable. Any physical problems or disruption that may occur as a result of climate change are likely to have a damaging effect on business operations. The GPRD region has been the most dynamic regional economy in China for more than two decades, attracting a significant percentage of Foreign Direct Investment (FDI) into China and acting as a major contributor to the country's total Gross Domestic Product (GDP). The impacts of climate change in the Pearl River Delta, therefore, could have serious economic repercussions for the country as a whole.

This article provides an overview of the scientific discussion of the potential effects of global climate change, focusing in detail on predictions for the GPRD region and the resulting environmental changes that might occur in the region. While fully supporting the critical need for mitigation (the effort to limit climate change by reducing greenhouse gas emissions), The purpose of this article is not to discuss mitigation strategies for the region. It deliberately makes the assumption that

1. We also wish to acknowledge the important contributions of Darren Lam. We must also thank Alexis Lau and Jimmy Fung of the Institute of the Environment at the HKUST for their advice on meteorology and climate, Dr. James Hansen of the Goddard Institute, NASA, USA on the latest scientific evidence, and Dr Tim Flannery for his expert comment.

2. Jared Diamond, "Why do some societies make disastrous decisions?", Lewis Thomas Prize Lecture, The Rockefeller Institute, New York City, Thursday 27 March 2003. 
changes will continue to occur at currently predicted rates, in order to examine the possible effects in the GPRD region. It then identifies a number of likely practical effects on the region's infrastructure and built assets and looks at potential effects on selected individual industry sectors that are important to the region. It concludes with a discussion of the measures that government and businesses will need to consider in order to adapt to these future conditions.

\section{Climate change predictions for the GPRD region}

Specific estimates of the effects in the GPRD region are subject to a high degree of uncertainty and are the subject of debate. Nevertheless, published climate projections for the GPRD region broadly concur with the Intergovernmental Panel on Climate Change (IPCC) ${ }^{(3)}$ analysis. The GPRD region encompasses Hong Kong, Macao and the Pearl River Delta of south-central Guangdong province, an alluvial plain formed by the lower west, north and east rivers of the Pearl River water system, characterised by a network of criss-crossing rivers and low elevations ${ }^{(4)}$. Ground level in the delta is close to MSL, with the northern and central parts lying at between 0.4 metres and 2.4 metres above sea level and the southern part of the delta slightly lower, ranging from 0.4 metres to -0.3 metres relative to $\mathrm{MSL}^{(5)}$. Since 1979, the area between Hong Kong and Guangzhou and around Macao has been rapidly developed, and former agricultural land converted to industrial use (see figure $n^{\circ} 1$ ). Forty million people are living in this region.

The northern fringe of the delta plain was reclaimed as early as the Tang Dynasty (around 1,400 years ago). The speed of reclamation has gradually increased since then, and during the last fifty years, reclaimed land was merged into just over one hundred enclosures, protected by flood defences. Much of the land recently developed into urban areas and industrial facilities lies in the flood plain of the Pearl River and its tributaries. Due to its topography, the history of land reclamation and the fact that much of the area is a natural flood plain, the GPRD region has always been under threat from natural hazards such as river or tidal flooding, typhoons and saline water intrusion. These will be intensified by climate change.

\section{Increase in temperature}

The Hong Kong Observatory (HKO) has published its predictions of temperature in the final decade of this century relative to the "climatological normals" of the period from
1961-1990. By that time, the HKO predicts that annual mean temperatures will have risen by $3.5^{\circ} \mathrm{C}$. The annual number of very hot days (maximum temperature of $33^{\circ} \mathrm{C}$ or above) in summer will roughly double, rising from 11 days to 24 days; while hot nights (minimum temperature of $28^{\circ} \mathrm{C}$ or above) will rise by 30 per year-four times the current normal level. The number of cold days (minimum temperature of $12^{\circ} \mathrm{C}$ or below) in winter will decrease from 21 to less than one day per year.

\section{Rainfall}

In East Asia and China, simulations have revealed that rainfall will increase under a scenario of doubled carbon dioxide concentration $^{(6)}$. The $\mathrm{HKO}$ predicts that average annual rainfall will increase by about $1 \%$ per decade in the 21 st century. This additional rainfall will not be evenly spread: the $\mathrm{HKO}$ also warns that year to year variability in rainfall will increase, meaning more years with either above average or below average rainfall. By the end of this century, the number of heavy rain days in a year is projected to increase by around one day per year. In the years of low rainfall, there will be increased pressure on water resources in the GPRD region, which are already under enormous stress from increased population, urban development and large-scale manufacturing operations, many of which are extremely water intensive. Conversely, heavy and prolonged rainfall may produce excess run-off (rainwater that neither evaporates nor penetrates the surface to become groundwater), which will increase the risk of flooding, already a serious problem throughout the GPRD region, and landslide damage.

\section{Storms}

There is some debate among climate scientists concerning the impact of global warming on the frequency and intensity

3. The Intergovernmental Panel on Climate Change (IPCC) was established in 1988 by two United Nations organisations, the World Meteorological Organisation (WM0) and the United Nations Environment Programme (UNEP), to evaluate the risk of climate change brought on by humans, based mainly on peer reviewed and published scientific/technical literature.

4. H. Yang, "Potential effects of sea-level rise in the PRD area: Preliminary study results and a comprehensive adaptation strategy," in J. N. Smitj et al., (ed), Adapting to Climate Change: an International Perspective, New York, Springer Verlag, 1996, 475 pp.

5. Huang Zhenguo et al., "Coastal inundation due to sea level rise in the PRD, China," in Natural Hazards, $n^{\circ} 33$, pp. 247-264, 2004.

6. Z. Zhao et al., "Advances on detection and projection of impacts of human activity upon climate change over East Asia and China," in 1999-2002 China National Report on Meteorology an Atmospheric Sciences for the 23rd General Assembly on International Union of Geodesy and Geophysics, Beijing, China Meteorological Press, 2003. 
of tropical cyclone activity. The HKO recently confirmed that there is not yet a definitive answer to whether tropical cyclone activity has or will increase due to global warming ${ }^{(7)}$. In fact, the $\mathrm{HKO}$ reports that "according to the observations in the past forty years, the annual number of tropical cyclones landing over the south China coast within $300 \mathrm{~km}$ of Hong Kong has been decreasing at a rate of about 0.17 per decade, from about three tropical cyclones in the 1960s to about 2.5 tropical cyclones in the 1990s. ${ }^{(8)}$ "Scientists from Hong Kong University of Science and Technology (HKUST) believe that it is likely that typhoons will track further east, meaning that they will be more likely to miss Hong Kong and hit Japan.

There is some emerging evidence, however, to suggest that warmer sea surface temperatures (SST) could lead to a modest increase in the intensity of tropical cyclones. Some Chinese scientists maintain that the unusual ferocity of the 2006 typhoon season, which began about a month earlier than usual and left thousands dead in southern China, was related to global warming. Qin Dahe, Director of the China Meteorological Administration, recently said that "against the backdrop of global warming, more and more strong and unusual climatic and atmospheric events are taking place. The strength of typhoons is increasing, the destructiveness of typhoons that have made landfall is greater and the scope in which they are travelling is farther than normal. (9)"

As it is, typhoons regularly hit southern China and can cause enormous destruction and loss of life where they make landfall. For example, Typhoon Prapiroon, in August 2006, killed more than fifty people and caused an estimated US\$675 million worth of damage in Guangdong province alone $^{(10)}$.

Even if there is no change to the current level of tropical cyclone activity, the destruction wreaked by storms in coastal regions can be expected to increase because of higher storm surges associated with higher sea levels. The likelihood and frequency of overtopping and breaches of coastal defences will be greatly increased. If climate change does in fact lead to more frequent or more violent tropical storms hitting the GPRD region in the future, the damage inflicted by these severe weather events could be intensified even further.

\section{Relative sea level rise}

A number of detailed studies have been carried out in China over the last 10-15 years which attempt to predict relative sea level rises in the GPRD region and the consequent risk of flooding and inundation of parts of the region. There is still a great deal of work to be done to reach agreement on the extent of the rise in sea level, its effects on water levels in the estuary and river systems and the consequent impact on the region.

There is a consensus, however, that sea level rise of some magnitude is happening and will continue to take place in the GPRD region, and that both the physical geography and urban development of the region render it extremely vulnerable to the effects of that sea level rise. Many lowland areas are likely to be inundated. Research led by Du Bilan of China's National Bureau of Oceanography in 2002 noted that the GPRD region is one of the regions most vulnerable to rising sea levels ${ }^{(I)}$.

Investigation by the Chinese Academy of Sciences in 1994 found that natural progradation (seaward change in the shape of the coastline due to build-up of sediment) of the coast and active land reclamation activities have resulted in an annual sea level rise of $0.5-1 \mathrm{~mm}$ in the distributaries in the estuarine area, which is expected to continue for some time. The Academy predicted that sea level in the GPRD region will rise $15 \mathrm{~cm}-30 \mathrm{~cm}$ by $2010,30 \mathrm{~cm}-40 \mathrm{~cm}$ by 2030 and $40 \mathrm{~cm}-60 \mathrm{~cm}$ by $2050^{(12)}$.

Coastal and river flooding in the Greater PRD is influenced by several factors: rainfall, high tide, high winds and typhoons, and storm surge. Due to backwater effects and the funnel-like shape of the estuary, water levels are higher upstream. A combination of weather and tidal factors which causes water levels to reach more than three meters is already well-known in parts of the Pearl River estuary. A $30 \mathrm{~cm}$ rise in sea level would have a significant impact on the high tide levels in the GPRD region. Similarly, increased sea level would magnify the effect of storm surges on the delta. On the occasions where all these weather and tidal factors coincide, storm surge in the region can be dramatic. When sea level rise is added into the equation, the potential for extensive flooding is considerable.

7. K. H. Yeung, Keynote Address III. Issues related to global warming - myths, realities and warnings, Hong Kong Observatory, June 2006, 16 pp.

8. Hong Kong Observatory, 1 August 2003, "Global warming - the Hong Kong connection". http://www.hko.gov.hk/wxinfo/news/2003/pre0801e.htm

9. Agence France Presse, "Warming reportedly behind China's killer typhoons," 15 August 2006. http://www.taipeitimes.com/News/world/archives/2006/08/15/2003323278

10. Dartmouth Flood Observatory, 2 October 2006. http://www.dartmouth.edu/ floods/ Archives/2006sum.htm

11. Zhang Zhiping, "Rising Seas Threaten Coastal Cities," in Beijing Review, 47, $n^{\circ} 9$, March 2004. http://www.bjreview.com.cn/200409/Nation-200409(A).htm

12. Earth Science Division, Chinese Academy of Sciences (ed), Impact of Sea Level Rise on the Deltaic Regions of China and its Mitigation, Beijing, Science Press, 1994, 353 pp. 

(1)

\section{Ecological impact}

Ecological problems that are likely to occur in the GPRD due to sea level rise include coastal erosion, salinisation of soil and groundwater and deterioration of shoals and marshes. This could cause the loss of coastal wetlands, a substantial change in the ecosystem and further encroachment on the habitat of rare species, according to Professor Chen Manchun, director of the Environment Department of China's National Marine and Data Service Centre, speaking in $2004^{(15)}$.

Flooding could result in increased sediment and nutrient levels in estuaries and coastal ecosystems, which has an enormous potential effect on habitat areas essential to many fish species. Wetlands in the GPRD, such as Mai Po in Hong Kong, the sixth largest coastal wetland in China, are important bird habitats and vital spawning grounds for many species of fish and invertebrates. These wetlands are seriously threatened by sea level rise and saltwater intrusion, and their ability to adapt naturally by retreating inland is blocked by human constructions, such as concrete roads and dikes or coastal defences.

\section{Impacts on infrastructure}

As discussed above, there is no firm consensus as to whether climate change is influencing the occurrence of more frequent or more severe tropical cyclones, but it is clear that larger concentrations of assets and populations in hazardprone regions, like the GPRD region, contribute substantially to higher financial losses from such events. As discussed in the previous section, the GPRD region could be extremely vulnerable to large-scale flooding from heavy rainfall, typhoons and storm surges. Floods can damage building structures and cause soil erosion which can lead to softening of building foundations. Resulting sedimentation can impact water management systems, damage buried pipes and semiburied tanks and harm dam structures and pump equipment ${ }^{(16)}$. Conversely, in dry periods, as soil moisture decreases, subsidence may affect underground pipes and cables. Windstorms bring additional loads to bear on buildings, affecting both structural and non-structural elements, but only minimally affecting foundations and underground elements. They can also damage distribution and high tension lines.

The GPRD region currently has infrastructure that is better than anywhere else in China. The extent of potential damage to infrastructure and buildings due to climate-related events is therefore significant. Flood control on the Pearl River relies mainly on levees and reservoirs. In 2001, there were 34 large reservoirs with a total storage capacity of 312 billion $\mathrm{m}^{3}$; and $11,000 \mathrm{~km}$ of dikes or levees. Levees along the main stream and the delta area are designed to withstand a ten- to twenty-year flood. Only the most important dikes have been designed according to a fifty to one hundred year flood and tide standard. Most infrastructure was originally planned in the 1950s, and was designed in accordance with the climate related estimates at that time. The 2003 study by the Guangdong Academy of Sciences warned that the present network of dykes and anti-flood measures would be inadequate in these circumstances ${ }^{(17)}$.

A general increase in temperature could have negative effects on elements of transportation infrastructure, which would cause disruption and require increased spending on repair and maintenance. Enormous investment is planned to develop an extended network of highways throughout the GPRD region, some of which will involve the construction of major bridge projects. In low-lying communities, roads tend to be lower than the surrounding lands so that land can drain into the streets, and are consequently the first to flood. In cities, road transportation is often greatly disrupted by repairs to underground water mains, pipes or electric cables. For example, in London increased shrinkage and expansion of the local clay caused by rising temperatures is expected to damage under-road water mains, meaning more frequent repairs and consequently greater disruption to road traffic ${ }^{(18)}$. Again, further research is needed to determine whether similar effects will be felt in the GPRD region. Rail links, such as the express rail train between Guangzhou and Hong Kong, are also an important element of the transportation infrastructure in the GPRD. Storms and flooding can disrupt rail transport and temporarily close stations, as well as causing damage to infrastructure. For example, during Typhoon Bilis in July 2006, flooding cut the main Guangzhou to Beijing railway line, stranding thousands of passengers. The underground train systems in Hong Kong, Guangzhou and Shenzhen, which are being rapidly built out at present, will also be vulnerable to flooding, as well as to possible effects

15. Zhang Zhiping, op. cit., 2004.

16. Paul Freeman and Koko Warner, Vulnerability of Infrastructure to Climate Variability: How Does this Affect Infrastructure Lending Policies?, Washington D. C. World Bank, October 2001

17. Guangdong Academy of Sciences, The Impact of Rising Sea Level on Guangdong Coastal Economy and Solutions, Guangdong Academy of Sciences, 2003.

18. London Climate Change Partnership, Climate Change and London's Transport Systems: Summary Report, Greater London Authority, September 2005, 30 pp. 
on tunnel structures caused by changes in groundwater, such as greater hydraulic pressure on the tunnel walls. The economic success of the GPRD was built on international trade, and the shipping and logistics sectors continue to make an important contribution to economic growth. The upper delta and western delta areas have serious silting problems that limit the operations of their ports, and for many years Hong Kong possessed the only deep-water, modern container facilities in the region. Several container ports have recently been developed in Shenzhen. Sea level rise, and its effects on storm surge and flooding, is a serious potential threat to harbour and wharf installations. Sea level rise and associated increase in storm surge will increase the probability of inundation of wharfs and breakwaters, reducing the wharf's working platform. Heightened wave action would also accelerate the scouring effect of the tide on hydraulic equipment, which could shorten its service life. Changes in sea level are likely to alter the balance of coast and beach erosion and sedimentation around harbours and their access channels ${ }^{(19)}$. This could pose significant operating challenges for ports in the region which already have a problem with sedimentation and is likely to increase their operating costs for additional dredging.

There are five airports in the GPRD region. Hong Kong has the leading airport at Chek Lap Kok, with over 36 million passengers in 2005. The new Baiyun Airport in Guangzhou, one of the three air hubs of China, is the largest and most advanced airport in China, handling over 20 million passengers and over 500,000 tonnes of cargo in 2004. Coastal cities, like Hong Kong, tend to have airports built along tidal waters, sometimes on reclaimed land. Therefore, their runways are vulnerable to flooding. Although Chek Lap Kok airport is currently at $6 \mathrm{~m}$ above sea level, the sea level rise predicted for the region could increase its vulnerability to flooding. Incremental damage could be caused if typhoons increase in intensity, including damage to parked aircraft, hangers or terminal buildings. As is the case for roads throughout the region, higher temperatures could also affect runways and airport roads, for example through deterioration of concrete, rutting or subsidence. Airports in the GPRD region may also be affected by damage to other transportation networks which affects delivery of aeroplane fuel or cargoes, thus slowing aeroplane turnaround time, or otherwise impacts on the operations of the facility.

\section{Impact on water resources}

Water resources in the GPRD region are already under pressure due to increases in demand caused by population growth and industrialisation. Development of water and sewerage management systems is not always adequate to meet these demands in certain areas, while unregulated exploitation of groundwater exacerbates problems of water quality and land subsidence. Climate change is likely to increase the stress on rivers already under pressure from salinity, over-allocation and declining water quality. Reduced rainfall would mean that less water is available for human consumption. Reduced water supply can also affect water quality in rivers, while drought conditions can increase erosion, leading to higher sediment loads entering rivers following rainfall events ${ }^{(20)}$. It is likely that water treatment facilities throughout the GPRD region would need extensive expansion and upgrading to cope with lower raw water quality. A rising sea will cause a large amount of tidal water to travel upstream in the delta. According to the China Climate Change Country Study's preliminary results in 1994 and investigations by the Chinese Academy of Sciences, the tidal boundary will move, bringing salt water further upstream: perhaps as far as $3 \mathrm{~km}$ further if there is a sea level rise of $40 \mathrm{~cm}$ to $60 \mathrm{~cm}$ in the GPRD region. Salt water will intrude even into Guangzhou in a low-water period, affecting the drinking water supply. Rising sea levels and heavy rains put pressure on drainage systems. When the sea level rises relative to ground level, storm water drainage pipes fill with sea water. The sea water may flow back up the pipes; or simply make it harder for rainwater to be discharged to the sea, resulting in both cases in flooding. Existing drainage systems in many GPRD cities are inadequate. Guangzhou, for example, regularly experiences tidal flooding caused by water intruding up through the drainage systems. This would clearly be worsened by sea level rise with resultant higher tides. Sea level rise and tidal saltwater intrusion upstream will also cause the GPRD region natural irrigation and drainage system to lose its effectiveness. It will become more difficult to drain waste water from cities and towns, which will increase pollution of the river network and embankment area.

19. Yang Guishan and Shi Yafeng, "Impacts of Sea Level Rise on Major Projects and Urban Development in China's Coastal Plains," in Journal of Chinese Geography, vol. 6, $n^{\circ} 4$, 1996, pp. 66-74.

20. Australian Greenhouse Office, Department of the Environment \& Heritage, Impact \& Adaptation - Water Resources, 2006, http://www.greenhouse.gov.au/impacts/ water.html

21. Fung Wing Yee, Characterising the Climate Change Impact in Hong Kong, Hong Kong, Environment Protection Department, 2004, 132 pp. 
U

\section{Power supply}

Climate change could have a significant impact on the infrastructure associated with fuel distribution and electricity transmission, both by increasing demand and disrupting supply.

Demand for energy is temperature sensitive, increasingly so as greater per capita incomes in the GPRD region increase the use of domestic air-conditioning and as industry in the region involves sophisticated manufacturing processes which require cooling and constant temperatures. Research carried out for Hong Kong's Environmental Protection Department in 2004 into the impact of global warming on the energy sector concluded that an increase in the ambient temperature of $1^{\circ} \mathrm{C}$ would increase electricity consumption by $9.02 \%$, $3.13 \%$ and $2.64 \%$ in Hong Kong's domestic, commercial and industrial sectors respectively ${ }^{(21)}$. As Hong Kong's industrial sector is extremely small, it can be estimated that this figure would be considerably higher elsewhere in the GPRD region.

While coal and diesel/fuel oil are used to generate the bulk of Guangdong's electricity supply (69\% of generating capacity in 2003), around one-fifth of supply is derived through hydro power. Hydroelectric dams are also considered to be vulnerable to climate change events. On the one hand, reduction of water flow in rivers during dry years could reduce the amount of power that can be generated.

\section{Economic impacts}

The science of climate change is still under development, and the analysis of the costs and economic impact of projected climate events is also at an early stage. While it is impossible here to make detailed economic forecasts for the GPRD region, this paper identifies some of the ways in which continued economic growth in the region, vital to the economy of China as a whole, could be threatened by climate change. As far as we know, no detailed analysis and quantification of the economic effects of climate change in the GPRD region has been published, although some estimates have been released in individual studies (some of which are quoted below). A great deal of further research in this area is required.

The GPRD region is extremely important to the economy of China as a whole. The region is an enormous contributor to national GDP, exports and industrial output, as well as attracting high levels of FDI and technology transfer to China (see table 1). It is an important industrial and consumer market and an important gateway to China. If the region suf-

\section{The GPRD's importance in China's economy}

\begin{tabular}{l|l}
\hline Land area & $0.4 \%$ \\
\hline Census population (2000) & $3.2 \%$ \\
\hline GDP (2004) & $9.9 \%$ \\
\hline Exports (2004) & $30.7 \%$ \\
\hline Imports (2004) & $28.4 \%$ \\
\hline FDI (2003) & $24.4 \%$ \\
\hline
\end{tabular}

Source: "The Greater Pearl River Delta".

fers, there would be a negative multiplier effect on the wider economy in China.

\section{Potential threats}

The PRD Economic Zone (PRDEZ), which is formed by the cities of Guangzhou, Shenzhen, Foshan, Zhuhai, Jiangmen, Zhongshan, Dongguan, four districts and counties of Huizhou and four districts and counties of Zhaoging, has been the most dynamic regional economy in China since the launch of China's reform programme in 1979. In the last fifteen years, the PRDEZ has become one of the world's leading manufacturing centres for electrical and electronic goods, watches and clocks, toys, garments and textiles, plastic products and other goods. Hong Kong has for many years been a regional centre for financial and professional services, and is one of the main transportation and logistics hubs in North Asia.

According to the World Bank, recent estimates indicate that sea level rise of one to five metres would reduce China's GDP by $2.4 \%$ to $10.8 \%{ }^{(22)}$. It is not clear what this would imply for the GPRD region, which is an enormous contributor to the country's GDP. Average growth in the PRDEZ over the last twenty-five years was over $16 \%$, compared to a national figure of 9.5\%, and GDP in the zone alone in 2004 was approximately 1,357.2 billion yuan (US\$163.9 billion) ${ }^{(23)}$, or $9.9 \%$ of China's total GDP. (GDP of the GPRD region, including Hong Kong and Macao, in 2004 was US\$336.98 billion) ${ }^{(24)}$.

22. P. Buys et al., Sea Level Rise From Global Warming: Potential Impact on Developing Countries, Washington D. C., World Bank, 2006.

23. Figure is slightly overstated as it includes the whole of Huizhou and Zhaoging, including parts that fall outside the defined area of the PRD economic zone see Michael J Enright et al., The Greater Pearl River Delta, Hong Kong, InvestHK, 2005, 146 pp. 
Several studies suggest that climate change could have a significantly harmful impact on the Pearl River Delta economy. For example, one simulation announced by the China Meteorological Administration in 2002 suggested that a historical high tide, combined with sea level rise of $65 \mathrm{~cm}$, would lead to flooding of about 3,400 square kilometres, causing an economic loss of 180.8 billion yuan (about US $\$ 21.9$ billion) ${ }^{(25)}$. For comparison, China's Ministry of Civil Affairs reported that between 1 January and 26 July 2006, flood-related disasters, including Typhoon Bilis, caused Guangdong province a direct economic loss of 19.9 billion yuan (approximately US\$2.5 billion) ${ }^{(26)}$.

There is no consensus on projected figures in the published studies, and no generally accepted methodology for analysing conditions, but it is clear that climate change could threaten economic performance in the GPRD region in many ways, some of which are outlined below.

\section{Allocation of public funds to disaster management}

Management of severe flooding events, caused by a combination of sea level rise and potentially violent weather, and occurring more frequently in future decades, would require significant financial resources. It is likely that government will bear the greatest part of the responsibility for many aspects of preparation and response, such as the following: monitoring and public warning systems, emergency response and evacuation of the public, cleaning-up operations, repair and replacement of public infrastructure, and economic assistance to communities and businesses.

While some funding for these activities may be drawn from the central government's budget, much of it is likely to come from local government funds. The necessary allocation to disaster management of capital which would otherwise have been invested in activities more directly related to economic activity, such as improved transportation infrastructure, technology or workforce training, may have an adverse effect on the level of economic growth in the region.

\section{Allocation of public funds to adaptation}

Greatly increased coastal and river defences will be required to protect the existing settlements of the GPRD region from increased flooding due to sea level rise. One estimate suggested that engineering work needed to raise the design standard of 95 key defences in the delta to meet a $30 \mathrm{~cm}$ sea level rise, would require 17.5 million cubic metres of soil and stone. Based on the price in 1998, the cost of this work-a fraction of the total infrastructure requirement-would be 2,103 million yuan (US\$262.9 million). Again, this defensive infrastructure may be funded from a variety of sources, but allocation of public funds to construction of sea walls and dikes will reduce the capital available to invest more directly in the GPRD region economy. In the longer term, it is possible that the results of cost-benefit analyses of adaptation alternatives will show that increasing coastal defences is no longer a sustainable strategy and that it is necessary to withdraw from some areas and relocate assets or communities. Such an operation would incur considerable costs, including compensation for foregone assets. It would also entail significant non-economic, social costs.

\section{Lower business revenues}

It is likely that there will be heightened risk of frequent business interruption in the GPRD due to climate change. As described above, transportation infrastructure is vulnerable to storm and flooding events and this could lead to major delays and bottlenecks, disrupting delivery of raw materials, components or finished goods. Much of the industry in the Pearl River Delta is supply chain driven and prompt delivery is vital to business competitiveness.

Electricity supply problems already hamper business operations in the Pearl River Delta. For example, in the first quarter of 2005, Guangzhou reported acute power shortages when power had to be restricted in specific areas on 716 occasions. Those periods cost the city 10 billion yuan (nearly US $\$ 1.3$ billion) in industrial output ${ }^{(27)}$. More frequent interruptions to power supply caused by damage to transmission lines or delays to fuel delivery could slow production and lower output even more seriously.

Lower output and loss of orders by factories in the GPRD region could impact seriously on the region's overall export earnings. In 2004, the PRDEZ exported goods worth US $\$ 182.43$ billion, which was equal to $30.74 \%$ of all China's exports. If buyers start to believe that companies in the GPRD region cannot reliably deliver, albeit due to external factors, they are likely to withdraw their custom and

24. Ibidem

25. "Global Warming Accelerates China's Sea Level Rise", in People's Daily, 13 April 2002.

26. International Federation of Red Cross, http://www.ifrc.org/docs/appeals/06/ MDRCN001a.pdf

27. Christine Loh, Energy Supply and Fuels Supply in Guangdong, Hong Kong, Civic Exchange, 2006. 
relocate their supply chain business outside the region. In addition to the manufacturing centre in the delta, this would also have a devastating impact on the ports and airports in the region and to the logistics and services industries in Hong Kong, whose companies have invested heavily in the Pearl River Delta.

\section{Increased taxation and business costs}

Greater pressures on the financial resources of the government at provincial or municipal level will, even if central government is willing to assist financially, almost certainly lead to increased taxation. This burden is likely to be heaviest on businesses and could include direct levies for flood control projects, as contemplated in the national Law of Flood Control, adopted in 1997. A higher tax burden on GPRD region businesses will increase their overall operating costs, with consequent negative effects on profits and on the level of retained earnings available for reinvestment or expansion of the businesses. Paradoxically, this may mean that total tax revenues collected by the government fall, even as the tax burden on individual companies or employees increases.

\section{Decreased foreign direct investment}

Loss of supply chain orders, lower turnover and higher business costs would generate less attractive returns to shareholders, which may decrease investor appetite for the region. Currently, foreign capital plays a major role in the GPRD's industrial development, with FDI into the PRDEZ in 2004 of US\$13.05 billion-over 24\% of total FDI into China. The Federation of Hong Kong Industries estimated in 2002 that there were 53,000 Hong Kong invested factories in the PRDEZ, and over 80,000 Hong Kong-invested factories in Guangdong as a whole. Much of this investment will have flowed through from FDI into Hong Kong itself, which in 2004 was a further US $\$ 13.63$ billion ${ }^{(28)}$. In that year, more than 3,600 overseas companies had regional offices in Hong Kong. It is likely that a sizeable reduction in FDI would significantly inhibit the region's ability to maintain the pace of industrial development and consequent economic growth. The delta area, particularly, might suffer not only from a reduction in capital investment, but also from a reduction in technology transfer by foreign investors, which has been instrumental in the development of local industry.

\section{Disruption of supply-chain production and transportation}

In the GPRD region, an extensive supply chain has taken shape, where it is convenient to source all parts, components and accessories of a product, so that upstream and downstream industries are closely connected and orders can be completed quickly. This inter-dependence on upstream and downstream activities may be an important factor in making manufacturing companies in the GPRD region vulnerable to climate change impacts. Supply chain companies typically run on very tight margins, and they compete on low cost and speedy delivery. Many companies could have very little flexibility to respond to delays or higher costs. Moreover, late deliveries of components or finished goods could very likely result in lost orders. While this could force individual companies out of business, the wider implications for the GPRD region as whole are also extremely grave. Once the efficiency of the supply chain in the region is called into question, international buyers could very rapidly choose to source goods and build a new supply chain infrastructure elsewhere in Asia, undermining the strong economic performance of the region.

The transportation, storage, post and telecommunications sector is the single largest service sector in the PRDEZ, with an output of US\$14.32 billion in 2003, equivalent to approximately $24 \%$ of the total service sector output in the PRDEZ. In Hong Kong in the same year, transport and storage recorded the third greatest output at US\$19.75 billion ${ }^{(29)}$. Hong Kong International Airport is the largest international air cargo handler in the world with a throughput of 3.4 million tonnes in 2005, which is expected to triple by 2020. Hong Kong's seaport handled 22.42 million Twenty Foot Equivalent Units (TEUs) (standard unit for containers) in 2005, and this volume is expected to increase to over 40 million TEUs by $2020^{(30)}$. Ports in the PRDEZ are also being expanded to handle increased volumes of freight, reaching a combined volume of 17 million TEUs in $2004^{(3)}$. Shenzhen, which has the fourth largest container port in the world, is also a logistics centre, with over 2,000 logistics companies located there, the top 32 of which have assets exceeding 100 million yuan ${ }^{(32)}$.

28. Michael J. Enright et al., op. cit., 2005

29. Michael J. Enright et al., op. cit., 2005.

30. Hong Kong Trade Development Council, http://www.investhk.gov.hk/pages/1/306.aspx

31. Hong Kong Trade Development Council, http://www.tdctrade.com/mktprof/ china/prd.htm

32. Idem. 
As described in detail above, climate change could negatively affect transportation infrastructure of all kinds in the GPRD. This would have a significant impact on the operations of both transportation and logistics companies.

Adaptation of transportation facilities would require additional capital expenditure include additional dredging to manage silting at port facilities; construction of flood defences, especially on wharfs and coastal airport runways; and elevation of road and rail networks and adaptation of tunnels and other infrastructure.

Damage and disruption of transportation networks can mean that companies may face penalties for delays; logistics companies compete on delivery time and could become uncompetitive; loss of business will hurt these companies' margins; relocation of supply chain business outside the region will greatly damage the sector; and passenger traffic may also be reduced.

Lower throughput of cargo and/or less passenger traffic would diminish core revenues for companies throughout this sector, such as airport operators: with regard to parking and landing fees, airport handling charges, lease payments from terminal concession and retail outlets; port operators: mooring fees, handling charges, lease payments from associated properties; ground transportation operators: road, bridge and tunnel tolls, service station revenues, ticket fares; airlines: ticket fares, cargo transportation fees; and shipping and logistics companies: freight forwarding fees, handling fees, warehousing charges, charter fees.

The impact of climate change on this sector would affect a wide range of companies, from airport and port operators, to airlines and shipping companies, to trucking and logistics companies. Both public and private sector operations could be significantly disrupted, with resulting loss of business. The sector has become increasingly dependent on the manufacturing activities in the GPRD region to power its growth, and there is likely to be a high degree of correlation between the economic performances of the two sectors.

\section{Adaptation}

The IPCC concluded in its Third Assessment Report that climate change is a reality and that adaptation is a necessary strategy to complement emissions mitigation efforts. While mitigation can be viewed as reducing the likelihood of adverse conditions, adaptation can be viewed as reducing the severity of many impacts if adverse conditions prevail ${ }^{(33)}$. An adaptation strategy aims to increase the resilience of natural, human and economic systems to possible changes and to re- duce the level of damage that might otherwise occur. It is a framework for managing future climate risk, which will influence both public policy and private sector decision-making.

\section{Adaptation strategy frameworks}

To be effective, an adaptation strategy must consider climate risk as a normal part of decision-making, allowing governments, businesses and individuals to reflect their risk preferences just as they would in other risk assessments and strategic plans ${ }^{(34)}$. While there will be many ways to develop adaptation strategies that are appropriate for specific users, a framework for considering the issues is likely to include the following: identification of vulnerability of region, economy, environment or population to climate change; identification of the likely impacts and ranking of these impacts in order of importance, probability and urgency; monitoring to assess whether anticipated climate changes are taking place, and if so, at what speed; calculation of the costs and benefits of a range of adaptation strategies: no response, relocation, physical infrastructure, change in business practice etc; sensitivity analysis of adaptation strategies and outcomes; awareness raising and communication with stakeholders about climate risk and adaptation; and ongoing risk assessment and strategic review.

To reach a point at which climate risk and adaptation strategies can be realistically assessed will require enormous activity across multiple fields. Better information on regional climate change and potential outcomes is a key requirement. Climate change modelling techniques are still under development and global climate models, or general circulation models, show large differences in the timing, direction and magnitude of climate change on a regional scale. Such differences often make it difficult for policy-makers to accept the results of vulnerability analyses and to address adaptation ${ }^{(35)}$.

\section{Responsibility for adaptation strategies in the GPRD region}

While climate risk analysis and adaptation strategy will need to be executed at all levels of both public and private sector

33. William Easterling et al., Coping with Global Climate Change: The Role of Adaptation in the United States, Arlington, Pew Centre on Global Climate Change, 2004, 40 pp.

34. Barrie Pittock (ed), Climate Change: An Australian Guide to the Science and Potential Impacts, Sydney, Australian Greenhouse Office, 2003.

35. http://www.gcrio.org/CSP/WORKSHOP 01 1996.html 
activity in the GPRD region, it is clear that strong government leadership is important. Much of the implementation of any adaptation strategy would inevitably be the responsibility of the national, provincial and local governments, given their key roles in public infrastructure, safety, health and land-use planning and control.

Most of the public infrastructure in China, for example, is owned by the state or by provincial government, which bears the responsibility for any damage to it. Governments also assume some risk for privately owned or managed infrastructure, as contracts governing most of these arrangements allocate financial responsibility for natural disasters to government parties ${ }^{(36)}$. In addition, where insurance is not widely available or used, the government will tend to take on reconstruction or renewal activities after a natural disaster. Key adaptation issues span virtually all portfolios and levels of government.

Due to the complex bureaucracy in China, co-ordination of climate change activities among the various bodies with authority over the GPRD region will be challenging. For example, taking water management as one area of activity, it is apparent that interaction between relevant national government departments and regional authorities is not straightforward. Despite the fact that the Ministry of Water Resources was mandated in 1998 to govern the management of water resources, water sector activities are fragmented, with other ministries handling water quality management, urban water supply and many other activities. Meanwhile, regional and municipal authorities represent their own interests, and there is often conflict between different regions and levels of government ${ }^{(37)}$.

Similarly, the leading agency for management of coastal regions in China is the Department of Sea Area Management, situated in the State Oceanic Administration (SOA). However, the SOA does not have the authority to co-ordinate all the sectors which may be affected by sea level rise: agriculture, industry, fisheries, tourism, urban planning, construction, ports, etc. In addition, the SOA is subordinated to the Ministry of Land Resources, which might indicate weak political standing. Moreover, at provincial and local level there are again many agencies, with varying levels of autonomy and their own priorities ${ }^{(38)}$.

Co-ordination could be improved if the GPRD region were to set up a dedicated body responsible for climate change strategy, as has been done in many other regions and cities in the world. For example, the UK government set up a task force, the UK Climate Impacts Programme (UKCIP) in 1997, and London has its own body, the London Climate Change Partnership. Several countries in Asia also have inter-agency task forces, including the Inter-Agency Commit- tee on Climate Change in the Philippines and the National Committee on Climate Change in Indonesia ${ }^{(39)}$.

In order to improve the understanding of the pace and extent of climate change effects in the GPRD region, it is vital to put in place an accurate monitoring network that will accumulate sufficient data to provide a scientific foundation for strategic decisions. For example, with regard to sea level rise, it will be necessary to monitor tides, vertical crustal movements, surface subsidence, coastal erosion, river bed and bay deposits, ground softening and subsidence ${ }^{(40)}$. A sea level rise of $30 \mathrm{~cm}$ by 2030 will require a comprehensive policy response. If no progress is made towards developing that policy in the immediate future, the GPRD region could be left extremely vulnerable.

Policy should be developed along several lines simultaneously, water resource management, flood management systems, coastal and river defence, long-term land use planning in order to protect the economy and communities of the GPRD region, and also to limit future actions that may increase existing problems. The implementation of any largescale policy decisions will require significant financial resources. One of the biggest challenges for policy-makers will be to allocate responsibility for funding their climate change initiatives. The central government budget for investment in the water sector, including flood control, is only $2-3 \%$ of the total capital investment budget ${ }^{(41)}$. At the provincial and municipal level, it seems that governments have been reluctant to invest in any areas that are not perceived to have a direct impact on GDP growth. It is likely that governments will seek to share the financial burden with the private sector in the GPRD region via increased taxes or specific fees for flood protection.

\section{Conclusion}

This article has identified some of the ways in which climate change may affect the landscape and economy of the

36. Paul Freeman and Koko Warner, op. cit., 2001.

37. Zhang Hai-lun and Wen Kang, "Flood control and management for large rivers in China", in Proceeding of Workshop on Strengthening Capacity in Participatory Planning and Management for Flood Mitigation and Preparedness in Large River Basins: Regional Cooperation in Flood Control Management in Asia and the Pacific, Phase II, Bangkok, November 2001, pp. 41-67.

38. "Coastal Zone Management in the People's Republic of China-A Unique Approach", M Lau, Centre for Marine and Climate Research, University of Hamburg, 2003.

39. http://www.gcrio.org/CSP/WORKSHOP_01_1996.html

40. H. Yang, op. cit., 1996

41. Zhang Hai-lun et al., op. cit., 2001. 
GPRD region. More in depth research and modeling remain be done so that the authorities, business and civil society can better understand climate impacts on the region, including ecological impacts. Economic valuation techniques should also be developed to allow more accurate assessment of the net costs of these impacts. It is clear that these impacts are broad, and that the region's response must likewise be so. Policy-makers in Hong Kong, Macao and Guangdong need to consider both mitigation and adaptation measures. In relation to mitigation measures, the goal must be to reduce the emissions of greenhouse gases. This needs to be driven by an explicit energy policy that promotes energy efficiency, energy conservation and demand-side management and promotes switching to renewable energy resources where possible, so as to reduce the burning of fossil fuels. It does not appear to be sufficiently appreciated by policy-mak- ers and businesses that the cheapest and fastest way to reduce greenhouse and other polluting emissions is to drive efficiency. This is likely due to a pervasive supply-led mindset. Policy-makers and businesses should look into the latest research on energy efficiency when considering mitigation measures, so that they become more familiar with demandside opportunities and compare relative costs to find the least cost and most effective path.

Finally, policy-makers and businesses in the GPRD region must start to incorporate climate change risk into all longterm policies, infrastructure projects and strategic investments. Around the world, decision-makers are beginning to realise they must be proactive rather than reactive to meet the challenge of climate change. Planning today for climate change and its potential risks is the only way to properly prepare the region and communities living here. 